\title{
Increasing Islamic Junior High School Students Learning Outcomes through Integration of Science Learning and Islamic Values
}

\author{
Nining Purwati \\ Postgraduate student, State University of Malang, Biology Education Program, Islamic \\ State University of Mataram, Indonesia, niningpurwati77@gmail.com \\ Siti Zubaidah \\ Prof., Departement of Biology, State University of Malang, Indonesia, \\ siti.zubaidah.fmipa@um.ac.id \\ Aloysius Duran Corebima \\ Prof., Departement of Biology, State University of Malang, Indonesia, \\ durancorebima@gmail.com \\ Susriyati Mahanal \\ Dr., Departement of Biology, State University of Malang, Indonesia, \\ susriyati.mahanal.fmipa@um.ac.id
}

\begin{abstract}
Learning results are influenced by several factors, including learning strategies. Islamic values-integrated learning is one of the strategies that can be applied to improve students' learning results. Science learning integrated with Islamic values provides the opportunity for students to relate the science knowledge with their concepts and experiences in real life as Muslims, so that students can feel that their learning is meaningful. This research is a quasi-experimental research aims to investigate the effect of science learning integrated with Islamic values on students' learning results. The learning materials taught in this research were substances and the changes, temperature and heat, and energy in living systems. The population of this research was seventh grade students of Islamic Junior High School (MTs) in West Lombok, Indonesia, which were taken by using cluster random sampling technique. The data were analysed using ANCOVA. The results of this research showed that science learning integrated with Islamic values had a significant effect on students' learning results with $\mathrm{p}=0.032$, and its' corrected mean score was $15.196 \%$ higher than that of the students taught by using the conventional learning.
\end{abstract}

Keywords: integrated learning, Islamic values, learning results, science, learning strategies, learning outcomes, learning

Citation: Purwati, N., Zubaidah, S., Corebima, A. D., \& Mahanal, S. (2018). Increasing Islamic Junior High School Students Learning Outcomes through Integration of Science Learning and Islamic Values. International Journal of Instruction, 11(4), 841-854. https://doi.org/10.12973/iji.2018.11453a 


\section{INTRODUCTION}

The objective of national education is to create a man of faith, fear of the Almighty Allah, noble, healthy, knowledgeable, skilled, creative, independent and responsible

(Indonesian Education Law No. 22 of 2003). This objective is in line with the objective of Islamic education, which is not solely aimed at obtaining intellectual and material satisfaction, or worldly achievement, but also forming rational and understanding human being who recognize the almighty Allah as the creator of man and the universe (Ma'zumi \& Jakaria, 2012). This objective can be an important basis of the teachers' efforts to achieve the students' learning results in the learning process.

Learning results can be influenced by various factors, one of which is meaningful learning. According to Novak (2002) and Hariyadi, Corebima, Zubaidah, \& Ibrohim (2018), meaningful learning can occur when students carefully decide to integrate newly acquired knowledge with the existing knowledge. Furthermore, it is stated that if students are intellectually-emotionally engaged, and creatively participate in creating the right situations in learning, then learning becomes meaningful. The meaningful learning was a learning that gave students the opportunity to learn and understand the concepts they learn directly through the real experiences linking the concepts integrated into the subject of the learning material (Zubaidah, Mahanal \& Yuliati, 2013).

Madrasah is an Islamic educational institution (Ma'zumi \& Jakaria, 2012; Hoel, 2016) which teaches students the basics of Islamic values and general science. Madrasah in Indonesia uses madrasah curriculum, which consists of $70 \%$ general subjects and $30 \%$ religious lessons (Tan, 2014). With the existence of religion subject, the awareness and the understanding of learning in Islam become an advantage for the process of integrating Islamic values and the implementation of learning (Baba, Salleh, Zayed, \& Harris, 2015). Furthermore, it is suggested that religious learning in madrasah has five to six hour meeting a week, while in general school religious learning has only two hour meeting a week. These madrasah characteristics give more opportunities for the implementation of integrated learning, which links the concepts of science with the students' real experience as Muslims, which in turn will lead to more meaningful learning.

In the context of science learning in madrasah, one way that can be done to create meaningful learning is to integrate the learning with the Islamic values. The embodiment of integrating Islamic values is by placing important sections contained in Qur'an and Hadith into natural science learning. According to Mansour (2008), integrating Islamic values into science learning illustrates that science is parts of Allah's creation. Qur'an has implicitly instructed to integrate religious values into general science. For example, the Qur'an in Surah al-Ghasyiyah verses 17-20 and An-nisa verse 82 clearly states that the entire material structure in the universe is filled with signs of Allah's power, but only the knowledgeable ones who pay close attention to these phenomena are aware of it.

Lubis (2015) argued that integrating Islamic values into science learning required the selection of effective approaches, strategies or methods in the learning process. In addition, the learning materials, such as syllabus, lesson plan, media, and other instruments must be well prepared and suitable, so that the implementation of 
integrating Islamic values in learning can successfully be carried out (Suyitno, Mulyono and Agustina, 2014). If this is carefully done, the process of internalizing Islamic values in students becomes easier (because students have achieved awareness) so that it is expected that character retention will be embedded in students. Yusnaeni, Corebima, Susilo and Zubaidah (2017) revealed that the learning strategy implemented by teachers played an important role in generating students' motivation and thinking awareness that would affect students' thinking ability and learning results. Hidayat (2009) through the results of his research confirmed that the success of integrating Islamic values into science learning was significantly determined by the teacher's background and Islamic knowledge.

According to Hakim (2012), the integration of Islamic values can be done by integrating materials on Islamic subjects (Qur'an Hadith, Aqidah Akhlak and Fiqih) with the science materials. In this case, the teachers' capability of using the appropriate teaching methods is required (Hassan, 2010). Teachers who do not have sufficient Islamic knowledge will not be able to integrate the learning with the Islamic values (Abdallah, Suhailah, and Hisham, 2011; Hashim, 2013). Furthermore, Kudari (2016) argued that through a combination of content material and the determination of academic skills and interactive skills, teachers could give a positive impact on students learning and development.

To teach science ideally means teaching all three aspects of scientific product, process, and attitude to students (Prayitno, Corebima, Susilo, Zubaidah, \& Ramli, 2017). Science teachers should be able to decide what students have to learn (product), how to learn (process) and the attitudes to be developed (Feng, 1987), so that the specific objective of science learning, which includes the development of knowledge, attitude and skills, can be achieved (Susilawati, 2012; Prayitno et al., 2017). Kasim \& Yusoff (2014) argued that the role of teachers in learning was not only for transferring knowledge, but also for integrating moral and spiritual values, building students' personality and character by facilitating, motivating and guiding students in their learning. Referring to the opinions proposed by Kasim \& Yusoff (2014), and to achieve the specific objectives of science learning, science learning should be integrated with moral and spiritual values. Hence, the integration of Islamic values in science learning is one of the strategies that can be done. Thus, students can have a holistic understanding and mindset, and the science learning can be meaningful.

The strategy of integrating Islamic values in science learning can be done by inserting the relevant verses of Qur'an and Hadith into the science learning material (Yasri, 2009); showing the signs of the power and majesty of Allah almighty on various scientific objects (Muspiroh, 2016); and revealing the benefits contained in Islamic religious worships. In addition to these strategies, teachers can also empower students through the use of learning resources that enable them to learn from the Qur'an. Ultimately, potential students who understand what they have learned can begin learning enthusiastically and participate in learning actively.

Research on the effect of integrating Islamic values in learning toward various aspects of learning (including learning results) has not been widely conducted. Generally, the research is descriptive qualitative research, namely research conducted by Rosidah 
(2008) and Adawiyah (2011). Based on the opinions and the results of research on integrating Islamic values in learning, it seems that there is a difference in learning results, which is affected by learning strategy integrated with Islamic values. Therefore, it is necessary to conduct a research, especially on science subjects, that aims to investigate quantitatively the differences in the learning results of seventh grade Islamic Junior High School or Madrasah Tsanawiyah (MTs) students in West Lombok Indonesia, who are taught by using the learning strategy integrated with Islamic values and the students taught by using the conventional learning. The selection of seventh grade Islamic Junior High School (MTs) students as the research subjects was based on the consideration that the cognitive development of Islamic Junior High School (MTs) students had reached the formal operational stage (> 11 years) (Piaget, 1970). At this stage, the students can think logically about abstract propositions, think more scientifically, and be able to make adjustment to the environment through the process of assimilation and accommodation.

\section{METHOD}

This research was a quasi-experimental research of a Pretest-posttest Non-Equivalent Control Group Design. This experimental research aimed at comparing the effect of science learning integrated with Islamic values compared to the conventional learning (not integrated with Islamic values) on students' learning results. The class taught using the integration of science learning and Islamic values was the experimental class, while the class taught using the conventional learning was the control class. The subject matters taught during the research were the substance and its changes, temperature and heat, and energy in the living system.

This research was conducted on seventh grade of Islamic Junior High School (MTs) students in the first semester of 2016/2017 academic year. Table 1 presents the design of this research.

Table 1

The quasi experimental design of non-equivalent control group design

\begin{tabular}{lll}
\hline Pretest & Treatment & Posttest \\
\hline $\begin{array}{l}\text { The pretest score of the } \\
\text { experiment class }\end{array}$ & $\begin{array}{l}\text { Learning Integrated with } \\
\text { Islamic values }\end{array}$ & $\begin{array}{l}\text { The post test score of the } \\
\text { experimental class }\end{array}$ \\
\hline $\begin{array}{l}\text { The pretest score of the } \\
\text { control class }\end{array}$ & & $\begin{array}{l}\text { The post test score of the } \\
\text { control class }\end{array}$ \\
\hline
\end{tabular}

\section{Sample}

The population of this research was seventh grade students from Islamic Junior High School (MTs) in West Lombok Region, namely MTs Negeri Model Kuripan, MTs Negeri Kediri, MTs Dakwah Islamiyah, MTs NW Nurul Haromain, MTs Islahuddiny, MTs Babussalam Bermi, and MTs Al-Aziziyah. The research samples were selected by using cluster random sampling, and MTs Dakwah Islamiyah selected as the sample which consisted of 8 classes. Student of class E was selected as the experimental class (taught using integrated learning strategy), and student of class $G$ was selected as the control class (taught using the conventional learning without being integrated with the Islamic values). 


\section{Instrument}

The data were collected using test. The instrument used was a test integrated with Islamic values in the form of subjective test. The following is the example of test items integrated with Islamic values used in this research.

"Our bodies cannot conduct the life process perfectly when the constituent parts are separates (not related). Explain the purpose of the sentence and complete it with an example! Write also a verse of Qur'an or Hadith that supports your explanation! "

The subjective tests were given at the beginning (pretest) and the end of the study (posttest). Before the instrument was used, the reliability and validity of the instrument was tested. The reliability refers to degree of test which are free from measurement error or an index that indicates the extent to which a measuring instrument is trustworthy. The validity test aims to determine the accuracy of the instruments to be used. In this research, the validity test performed included content validity, construct validity and empirical validity. Content validity is the accuracy of the instrument in terms of the content of the instrument, which is estimated to be in accordance with the curriculum. The construct validity is related to the suitability of the construct of the instruments with the ability to be measured. The empirical validity is the validity obtained from experience (Arikunto, 2009). The content validity and construct validity in this research were done by experts of learning assessment, while the empirical validity was conducted on 72 MTs students (Islamic Junior high school students) in West Lombok.

The results of the reliability test using Alpha Cronbach showed that the test instrument had high reliability criteria with a score of 0.703 . This means that the instrument has a high reliability level to be used. The results of the validity test by the experts showed that all the test items (14 items) were valid in content and construct, whereas based on the empirical validity test, 8 items were declared valid. Therefore, 8 test items were used in this research, while the remaining test items were not used because they did not meet the criteria of validity.

\section{Implementation}

Table 1 shows that in this research two learning strategies were implemented, namely a learning strategy integrated with Islamic values and a conventional learning. The learning strategy integrated with Islamic values was carried out by inserting the relevant Islamic values contained in the Qur'an and Hadith into the learning materials, by revealing the benefits contained in the Islamic worship, and by demonstrating the power and majesty of the Allah in the creation of various natural science objects.

The strategy of integrating the values of Islam was done on the aspects of the learning material and on the process, starting from the pre activity until the post activity on the learning activities which are reflected in the lesson plan. The Lesson plan was developed by referring to the guide book of science learning integrated with Islamic values containing science learning material and the Islamic values contained in the Qur'an and Hadith which were relevant to the learning material.

The conventional learning was carried out by not inserting the Islamic values either in the science learning material or during the learning process. In this case, the science 
learning material and the learning process were not related to the relevant Islamic values, neither from Qur'an nor from Hadith. In this learning, the lesson plans used were developed based on the characteristics of natural science learning materials and not referring to the natural science guide book integrated with Islamic values.

In the learning strategy integrated with the Islamic values, at the beginning, the students were asked to read the verses of the Quran and its translations related to science learning materials being discussed. The verses of the Qur'an were selected on the basis of their relevance to the content of the natural science learning material. The selection of the verses of the Qur'an was contained in the lesson plans whose development referred to the natural science guide book integrated with Islamic values. The selection of the verses of Al-quran was carried out by using verse software (ayat software). For example, related to the learning material of substance and its changes, the students were asked to read the verses such as;

"Do you not see that Allah drives clouds? Then He brings them together, then He makes them into a mass, and you see the rain emerge from within it, and $\mathrm{He}$ sends down from the sky, mountains [of clouds] within which is hail, and $\mathrm{He}$ strikes with it whom $\mathrm{He}$ wills and averts it from whom $\mathrm{He}$ wills..." (Qur'an, 24:43).

Furthermore, the students were asked to discuss the substance forms and its changes that occur based on the verses of the Qur'an and present the results of their discussion. After that, the teacher presented the science learning material about the substance and its changes, reinforced the students' answers, improved and/or provided inputs on the opinions expressed by the students and revealed the Allah's greatness and power in managing the changes that occurred. At this stage, the teachers had embedded the Islamic values of faith and morals (attitudes toward Allah) for the blessings that have been granted.

At the end of the lesson, the teacher integrated the Islamic values again. The teacher and students drew conclusions of the learning and expressed the benefits contained in the natural events that occurred on earth. Thus, it is instilled in the students' mind that the natural phenomena are the evidence of Allah's existence and power as the creator of the universe. The integration of Islamic values was not only done during the learning activities but also during the evaluation. The integration of Islamic values was reflected in the question items used, namely by associating the science learning material with the verses of the Qur'an or Hadith which are relevant to science concepts. The question forms of the integration of Islamic values have been presented in the research instrument section of this paper.

\section{Data analysis}

The research data were analyzed using ANCOVA. Before the data were analyzed, the prerequisite tests were performed, which included test of (1) the normality and (2) the homogeneity. The data analysis and the prerequisite tests were performed by using SPSS version 23 . 


\section{FINDINGS AND DISCUSSION}

The effect of science learning integrated with the Islamic values on the students' learning results can be known from ANCOVA test with a significance level of 5\%. Prior to the data analysis, the normality test using One-Sample Kolmogorov-Smirnov test and the homogeneity test using Levene's Test of Equality of Error Variances were performed. The results of the analysis show that the data are normally distributed $(\mathrm{p}=$ 0.075 for pretest; $p=0.200$ for post test $)$ and the data are homogeneous $(p=0.683)$. Results of tests were presented in Table 2, Table 3 and Table 4.

Table 2

Results of normality test

\begin{tabular}{llll}
\hline & & Pretest & Postest \\
\hline $\mathrm{N}$ & & 64 & 64 \\
\hline \multirow{2}{*}{ Normal Parameters } & Mean & 22.78 & 31.81 \\
\cline { 2 - 4 } & Std. Deviation & 11.379 & 12.899 \\
\hline \multirow{2}{*}{$\begin{array}{l}\text { Most Extreme } \\
\text { Differences }\end{array}$} & Absolute & 0.105 & 0.071 \\
\cline { 2 - 4 } & Positive & 0.105 & 0.071 \\
\cline { 2 - 4 } & Negative & -0.097 & -0.057 \\
\hline Test Statistic & & 0.105 & 0.071 \\
\hline Asymp. Sig. (2-tailed) & & 0.075 & 0.200 \\
\hline
\end{tabular}

Table 3

The results of homogeinity test

\begin{tabular}{llll}
\hline $\mathrm{F}$ & df1 & df2 & Sig. \\
\hline 0.168 & 1 & 62 & 0.638 \\
\hline
\end{tabular}

Table 4

Results of ANCOVA analysis

\begin{tabular}{lcccc}
\hline Source & df & Mean Square & F & Sig. \\
\hline Corrected Model & 2 & 2171,409 & 21.576 & 0.000 \\
\hline Intercept & 1 & 3135.582 & 31.157 & 0.000 \\
\hline Pre & 1 & 4018.817 & 39.933 & 0.000 \\
\hline Model & 1 & 483.978 & 4.809 & 0.032 \\
\hline Error & 61 & 100.638 & & \\
\hline Total & 64 & & & \\
\hline Corrected Total & 63 & & & \\
\hline
\end{tabular}

Table 4 shows that the $\mathrm{F}$ value $=4.809$ with the significance value of 0.032 . Thus, the learning strategy integrated with Islamic values has a significant effect on the learning results of seventh grade Islamic Junior High School (MTs) students in West Lombok Indonesia. To know the difference in the learning results between the experimental class and the control class, the corrected mean score is calculated. The corrected mean score of the learning results of the students taught by using the learning strategy integrated with Islamic values is $15.196 \%$ higher than that of the students taught by using the conventional learning. 
The results of this research are consistent with the research conducted by Mauluddiana (2015) which revealed that learning using mathematics interconnection approach of the Qur'an in the selected verses had an effect on students' learning results, and the research by Isnawati (2012) reported that the integration-interconnection between Islamic Education learning and the general lesson can improve students' achievement.

Science learning integrated with Islamic values is one of the learning that attempts to correlate learning material into students' real life. This learning can guide the students' thinking process and help students learn to think logically (Muspiroh, 2013) and develop the faith and piety of students (Sunhaji, 2013). While the learning which does not integrate Islamic values or out of the students' real world context is less able to develop students' thinking skills holistically. As a result, students have difficulty in connecting concepts they gain with their real lives as Muslims and cannot feel the meaning and advantages of every lesson they have learned for their real life.

The study conducted by Baba et al. (2015) showed that directly or indirectly, the integration of Islamic values made the learning process more valuable and meaningful. According to Hoel (2016), the instilling of Islamic values in learning is relevant to the students' real life, thus facilitating them in learning. Meaningful learning is a learning that enables students to connect new knowledge gained with relevant concepts and experiences that have been previously owned (Novak, 2002; Zubaidah et al., 2013).

The strategies of integrating Islamic values in this research enable the students to gain meaningful learning. The placement of important points contained in the Qur'an and Hadith in learning is a spiritual strategy (Sabki \& Hardaker, 2013). In this learning, the students can relate the science knowledge they gain with the basic concepts of Islam and their religious experiences as Muslims. Every science material learned by students and associated with their daily life will be able to help students feel the meaning of each learning material and implement them in various aspects of life (Sahlan, 2013; Zubaidah, Fuad, Mahanal, \& Suarsini, 2017). Furthermore, it is stated that the learning material is not only functionally meaningful, but also will be strongly embedded in the student's memory, so that it is not easily forgotten.

Rustham \& Arifin (2012) and Fuad, Zubaidah, Mahanal, \& Suarsini (2017) stated that the use of effective learning methods can help to achieve the learning objectives. In the learning integrated with Islamic values, an approach, a strategy, and a method of integrating Islamic values into learning materials are necessary. This, in turn, will encourage students to learn better and produce better learning results. Hsu (1994) stated that the provision of lesson content in science could develop reasoning and metacognitive skills. Meanwhile, Tatar, Tüysüz, Tosun, \& İlhan, (2016) claimed that one of the factors affecting achievement of science and becoming the most predictor is the content of learning source that may arouse the learners' curiosity. Thus, it can be said that the science learning material taught by integrating religious learning materials (Islamic values) can improve students' learning results. Rosidah (2008) revealed that learning that integrating science and Islamic values had a positive effect on improving students' learning results. Furthermore, Adawiyah (2011) stated that the integration of 
religious values in chemistry learning had a positive effect on improving the three aspects involved in students' attitude, namely, cognitive, affective and conative aspects.

The use of learning methods that activate the parts of the brain can increase the memory capacity from time to time, make thinking process more visible, strengthening memories and make learning better (Nawaz \& Jahangir, 2015; Fuad et al., 2017). According to Ghilan (2014), when one's attention focuses on listening to and reading the Qur'an, the hippocampus area in the temporal lobe of the brain will be stimulated. The same thing will happen to the frontal lobe and the cerebral cortex, which is a part of the brain which is responsible for memory work, memory recovery, planning, continuous attention and social attitudes. Furthermore, Baba et al. (2015) suggested that the activity of reading the Qur'an and memorizing it indirectly made students became more powerful and remembered the lessons easily, not only about the verses related to the science materials, but also vice versa. Thus, students will achieve success in learning more easily.

According to Kasim \& Yusoff (2014), the integration of learning material with spiritual moral values brings its own internal harmony which becomes the source of mental health and emotional stability. This awareness of both mental health and emotional stability regulates the physical and psychological needs of a Muslim both in his personal behavior and social behavior. More specifically, Rifa'ah (2013) stated that the reading of Qur'an had an effect on the mind peacefulness.

One of the activities in this research (in the experimental class) was that the students were asked to read the verses of Qur'an that were relevant to the science material being studied. In accordance with Rifa'ah (2013), this activity is believed to help students gain peace in the learning process and improve students' positive attitude toward science. The positive attitudes are such as realizing the order and beauty of the universe and praising the power and greatness of Allah almighty. This attitude is a spiritual attitude that can be generated in students through natural science learning integrated with Islamic values. Bachtiar, Zubaidah, Corebima and Indriwati (2018) revealed that students' spiritual attitudes could also be developed through the use of various learning models, such as problem-based learning (PBL) and cooperative learning models. These learning models can encourage students to interact with each other and to contribute to the learning that will ultimately contribute to the development of their spiritual attitudes. Sari (2010) revealed that the students' positive attitudes toward science could encourage students to learn better and produced better learning results. This is proven by the research results showing that student learning results in the class taught by integrating Islamic values were better compared to the class taught not by integrating Islamic values. Thus, it is possible that if the integration of Islamic values into natural science learning is done by using various specific learning models that are in accordance with the characteristics of natural science, the students' learning results will easily improve, not only on the cognitive aspect but also on the affective and psychomotor aspects.

The integration of Islamic values into the learning aims to improve the field of science as well as the quality of faith and devotion (Hariyani, 2013). More specifically Ramli (2014) asserted that the integration of Islamic values into the related parts of science learning is an attempt to develop a Muslim personality among students and to make 
Islamic teachings as a guide for life, as well as to form a balanced person physically, intellectually, spiritually and emotionally (Kasim \& Yusoff, 2014). According to Djudin (2011), the integration is done in order that the students do not fall into the teachings that are contrary to the creed (aqeeda) and faith.

In the science learning integrated with Islamic values, everything is associated with the awareness of the order and beauty of the universe (the object of science learning) and the praise of Allah's power and majesty. Thus, in addition to be viewed as a form of worship, the process of science learning is also viewed as a form of dzikir to Allah. Our hearts become calm when remembering Allah and our hearts are satisfied when we feel that Allah is the protector and the helper. In other words, the integration of Islamic values into the actual problems experienced by students, both at home, at school and in the community, is good for the students' emotional intelligence (Riyadi, 2015).

When learning is integrated with Islamic values, the admiration and happiness are seen and radiated in students. The admiration and the happiness will improve students' motivation in learning and make it easier for them to achieve better learning results (Rustham \& Arifin, 2012). Baba et al. (2015) revealed that in the learning integrated with Islamic values, the students and teachers learned about sincerity, sensitivity, sympathy and responsibility that made them closer to one another. The learning materials which are integrated with Islamic values will motivate students to change and vary their way of thinking and attitude. Rohim (2010) reported that the learning by using mathematical-Islamic integration approach through cooperative learning model of Student Teams Achievement Division (STAD) could improve the students' learning motivation. According to Bahri and Corebima (2015), students who have motivation in learning will have a careful attention to the learning material, read the learning material in order to understand the content of the lesson and use various learning strategies. The students having motivation will actively involve in their learning process (Adegboyega, 2018).

\section{CONCLUSIONS}

Based on the results of this research, it is found that the mean score of the students' learning results in the natural science learning integrated with Islamic values is higher than that of the students in the natural science learning not integrated with Islamic values. The corrected mean score of the students' learning results who learned using the learning integrated with Islamic values was $15.196 \%$ higher than that of the students who learned using the conventional learning. Thus, it can be concluded that science learning integrated with Islamic values had a significant effect on the learning results of seventh grade Islamic Junior High School (MTs) students in West Lombok Indonesia.

\section{IMPLICATIONS AND RECOMMENDATIONS}

The results of this research have implications on the success of the implementation of natural science learning integrated with Islamic values in Madrasah, which so far the religion subject and natural science learning are separately taught. The Islamic values integrated into natural science learning are the values that originate from Qur'an and Hadith. The process of integrating the Islamic values into Science learning can be done 
by various strategies, such as, by inserting the relevant verses of Qur'an or Hadith into the content of natural science learning material, showing the majesty and power of Allah on various objects of natural science, for example, in the process of setting up the universe and the creation of human beings and other creatures, and by expressing the wisdom contained in the Islamic prayers. The integration of Islamic values into natural science learning in Madrasah becomes easier due to the unique characteristics of Madrasah as an Islamic educational institution that aims to form a generation that believes in, loves knowledge and has a global view to gain happiness in the world and the hereafter.

The science teachers, especially science teachers in madrasah, are recommended to implement the science learning integrated with Islamic values based on the syntax of particular learning models which are suitable with the characteristics of the science learning. In addition, further research is needed to reveal the effect of the learning integrated with Islamic values on the other aspects, such as students' metacognitive skills and attitudes.

\section{REFERENCES}

Abdallah, SS., Suhailah Hussien, S., and Hisham, N.A. 2011. The Experience of Islamization of Knowledge at the International Islamic University Malaysia, in New Intellectual Horizons in Education, ed. Yedullah Kazmi (Kuala Lumpur: IIUM Press, 2011): 91-111.

Adawiyah, R. (2011). Pengaruh Pengintegrasian Nilai pada pembelajaran Kimia dengan Pendekatan Pembelajaran Kooperatif Teknik TGT terhadap Sikap Siswa [The Effect of the Integration of Values into Chemistry Learning with cooperative Learning Approach of TGT on Student Attitude]. (Unpublished master's thesis). UIN Syarif Hidayatullah, Jakarta

Adegboyega, L. O. (2018). Influence of Achievement Motivation on Nigerian Undergraduates' Attitude towards Examination. International Journal of Instruction, 11(1), 77-88.

Arikunto, S. (2009). The Fundamentals of Education (Revised edition). Jakarta: Bumi Aksara.

Baba, S. B., Salleh, M. J., Zayed, T. M., \& Harris, R. (2015). A Qur'anic Methodology for Integrating Knowledge and Education: Implications for Malaysia's Islamic Education Strategy. The American Journal of Islamic Social Sciences, 32 (2): 1-27.

Bachtiar, S., Zubaidah, S., Corebima, A. D., \& Indriwati, S. E. (2018). The Spiritual and Social Attitudes of Students Towards Integrated Problem Based Learning Models. Issues in Educational Research, 28(2): 254-270.

Bahri, A., \& Corebima, A. D. (2015). The Contribution of Learning Motivation and Metacognitive Skill on Cognitive Learning Outcome of Students Within Different Learning Strategies. Journal of Baltic Science Education, 14(4): 487-500.

Djudin, T. (2011). Menyisipkan Nilai-Nilai Agama Dalam Pembelajaran Sains: Upaya Alternatif Memagari Aqidah Siswa [Inserting religious Values into Science Learning: alternative Efforts to strengthen the Students' Aqidah]. Khatulistiwa, 1 (2): 151-160. 
Feng, J. (1987). Science, Sciencing and Science Education: An Integrated Approach to Science Education in Early Childhood. Memphis: Memphis State University.

Fuad, N. M., Zubaidah, S., Mahanal, S., \& Suarsini, E. (2017). Improving Junior High Schools' Critical Thinking Skills Based on Test Three Different Models of Learning. International Journal of Instruction, 10(1): 101-116.

Ghilan, M. (2014). How the Quran Shapes the Brain. http://www.aimislam.com/ accessed on 16 January 2017.

Hakim, L. (2012). Internalisasi Nilai-nilai Agama Islam dalam Pembentukan Sikap dan Perilaku Siswa Sekolah Dasar Islam Terpadu Al-Muttaqin Kota Tasikmalaya [Internalization of Islamic Values into the Formation of the Attitudes and Behavior of Students of integrated Islamic Primary School Al-Muttaqin Tasikmalaya]. Jurnal Pendidikan Agama Islam-Ta'lim, 10 (1): 67-77.

Hariyadi, S., Corebima, A. D., Zubaidah, S., \& Ibrohim. (2018). Contribution of Mind Mapping, Summarizing, and Questioning in the RQA Learning Model to Genetic Learning Outcomes. Journal of Turkish Science Education, 15(1): 80-88.

Hariyani, M. (2013). Integrasi Nilai-nilai Islam dalam Pembelajaran Matematika di SD/MI [Integration of Islamic Values in Mathematics Learning in SD / MI]. Jurnal Primary, 05 (01): 1-12.

Hashim, R and Abdallah, SS. 2013. Islamization of Human Knowledge in Theory and Practice: Achievements, Challenges and Prospects in the IIUM Context. IIUM Journal of Educational Studies. 1(1): 1-12.

Hassan, M. K. (2010). A return to the Qur'anic paradigm of development and integrated knowledge: The Ulu al-Albab model. Intellectual Discourse, 18(2): 183-210.

Hidayat, S. (2009). Integrating the Islamic Values in Science Learning (IPA) in Elementary Schools (Descriptive-Qualitative Study in Elementary School Al-Muttaqin Full Day School), Tasikmalaya. (Unpublished master's thesis). Universitas Pendidikan Indonesia, Bandung.

Hoel, N. (2016). Exploring Women's Madrasahs in South Africa: Implications for the Construction of Muslim Personhood and Religious Literacy, Religious Education, 111 (1): $30-48$.

Hsu, T. E. (1994, Februari). Effects of learner cognitive styles and metacognitive tools on information acquisition paths and learning in hyperspace environments. Proceedings of Selected Research and Development Presentations at the 1994 National Convention of the Association for Educational Communications and Technology (pp. 291-308).

Indonesian Education Law No. 22 of 2003

Isnawati, D. (2012). Integration-Interconnection of Islamic Learning and General Learning in Second Grade Students at SDIT Sunan Averroes Yogyakarta. (Unpublished master's thesis). UIN Sunan Kalijaga, Yogyakarta.

Kasim, T.S.A.T., \& Yusoff, Y.M. (2014). Active Teaching Methods: Personal Experience of Integrating Spiritual and Moral Values. Religious Education, 109(5): 554-570.

Kudari, JM. 2016. Survey on factors Influences the Student's Academic Performance. International journal of Emerging Research in Management \& Technology, 5(6): 30-36. 
Lubis, M. A. (2015). Effective Implementation of the Integrated Islamic Education. Global Journal Al-Thaqafah, 5(1), 59-68.

Mansour, N. (2008). The Experiences and Personal Religious Beliefs of Egyptian Science Teachers as a Framework for Understanding the Shaping and Reshaping of their Beliefs and Practices about ScienceTechnology-Society (STS). International Journal of Science Education, 30(12): 1605-1634.

Mauluddiana, N. L. (2015). The Effect of Learning based on Mathematics-Al-Qur'an Interconnection Approach in the selected Verses with the Subject of Set on the Mathematics Learning Results of Class VII Students of MTs Al-Umron Bendosewu Blitar in the 2014/2015 academic Year. (Unpublished master's thesis). Fakultas Tarbiyah dan Ilmu Pendidikan IAIN Tulungagung, Tulungagung.

Ma'zumi \& Jakaria. (2012). Contributions of Madrasah to The Development of the Nation Character. International Journal Of Scientific \& Technology Research Volume 1, Issue 11 December 2012.

Muspiroh, N. (2016). Integrasi Nilai Islam Dalam Pembelajaran IPA (Perspektif Pendidikan Islam) [Integration of Islamic Values into Science Learning (Islamic Education Perspective)]. Jurnal Pendidikan Islam, 28(3): 484-498.

Nawaz, N., \& Jahangir, S.F. (2015). Effects of memorizing Quran by heart (Hifz) on later academic achievement. Journal of Islamic Studies and Culture, 3(1): 58-64.

Novak, J. D. (2002). Meaningful learning: The essential factor for conceptual change in limited or inappropriate propositional hierarchies leading to empowerment of learners. Science education, 86(4): 548-571.

Piaget, J. (1970). Piaget's Theory (G. Gellerier \& J. Langer, Trans.). In: P.H. Mussen (Ed.), Carmichael's Manual of Child Psychology (3rd Edition, Vol. 1). New York: Wiley.

Prayitno, B. A., Corebima, D., Susilo, H., Zubaidah, S., \& Ramli, M. (2017). Closing the science process skills gap between students with high and low level academic achievement. Journal of Baltic Science Education, 16(2): 266-277.

Ramli, M. (2014). Integrasi Pendidikan Agama Islam ke dalam Mata Pelajaran Ilmu Pengetahuan Alam di Madrasah Tsanawiyah Negeri Mulawarman Banjarmasin [Integration of Islamic Religious Education into Natural Science Learning at State Madrasah Tsanawiyah Mulawarman, Banjarmasin]. Ittihad, 12(21): 111-132.

Rifa'ah, S. (2013). Pengaruh motivasi membaca Al-Qur'an terhadap ketenangan jiwa santriwati pondok pesantren putri Al-Hikmah Tugurejo Tugu Semarang [The Effect of Motivation to read Al-Qur'an on the Peace of Mind of Female Students of Al-Hikmah Islamic Boarding Schools Tugurejo Tugu Semarang]. (Unpublished doctoral dissertation). IAIN Walisongo, Semarang.

Riyadi, I. (2015). Integrasi Nilai-Nilai Kecerdasan Emosional Dalam Kurikulum Pendidikan Agama Islam Di SMA: Perspektif Daniel Goleman [Integration of emotional Intelligence Values in Islamic Education Curriculum of Senior High Schools: Daniel Goleman's Perspective]. Hunafa: Jurnal Studia Islamika, 12(1): 141-163.

Rohim, A. (2010). The Efforts to Improve the Students' Mathematics Learning Motivation with Mathematics-Islam Integration Approach through Cooperative Learning Model of 
STAD (Case Study in Science Class XI MA Nahdhatul Muslim Undaan Kudus). (Unpublished doctoral dissertation). UIN Sunan Kalijaga, Yogyakarta.

Rosidah. (2008). The Effect of the Integration of Science and Islam using Discussion Method on Biology Learning Results with the Sub Subject of Archaebacteria to Class X Students of Madrasah Mu'allimat Muhammadiyah Yogyakarta in 2007/2008 Academic Year. (Unpublished master's thesis). UIN Sunan Kalijaga, Yogyakarta.

Rustham, N. \& Arifin, M.A.A.R. (2012). Teaching Methodologies in a Weekend Madrasah: A Study at Jamiyah Education Centre, Singapore. International Journal of Arts and Commerce (IJAC), 1(2): 148-167.

Sabki, A.A \& Hardaker, G. (2013). The Madrasah Concept of Islamic Pedagogy. Educational Review, 65(3): 342-356.

Sahlan, A. (2013). Pembelajaran Pendidikan Agama Islam Dengan Pendekatan Kontekstual [Islamic Education Learning in Contextual Approach]. Jurnal el-hikmah Fakultas Tarbiyah UIN Malang, 8(2): 217-227.

Sari, M. (2010). Learning Strategies and Methods in Biology Learning Based on Imtaq in schools / Madrasah. Jurnal Ta'dib, 13(2): 134-151.

Sunhaji, S. (2013). The Implementation of Integrated Learning in The Islamic Religious Education to Raise the Faith Devotion of the Students of State Senior High Schools in Purwokerto. Dewantara, 1(1): 58-67.

Susilawati. (2012). Karakter Religius Pembelajaran IPA [Religious Character of Science Learning]. Jurnal Pendidikan Islam, 17(1): 98-114.

Suyitno, H. Mulyono and Agustina W. (2014, September). Integration of Character and Realistic Education in Mathematics Classroom Learning Process. In Sutikno., Widiyatmoko, S., \& Harjito (Eds.). Proceedings of International Conference On Mathematics, Science, and Education (pp. 309-316). Semarang: Semarang State University.

Tan, C. 2014. Educative Tradition and Islamic Schools in Indonesia. Journal of Arabic and Islamic Studies 14: 47-62.

Tatar, E., Tüysüz, C., Tosun, C., \& İlhan, N. (2016). Investigation of Factors Affecting Students' Science Achievement According to Student Science Teachers. International Journal of Instruction, 9(2), 153-166.

Yasri. (2009). Strategi Pembelajaran Matematika yang Bernuansa Islami [Mathematics Learning Strategy with Islamic Nuance]. Online. http://bdkpadang.kemenag.go.id accessed on 12 October 2016.

Yusnaeni, Corebima, A. D., Susilo, H., \& Zubaidah, S. (2017). Creative Thinking of Low Academic Student Undergoing Search Solve Create and Share Learning Integrated with Metacognitive Strategy. International Journal of Instruction, 10(2): 245-262.

Zubaidah, S., Fuad, N. M., Mahanal, S., \& Suarsini, E. (2017). Improving Creative Thinking Skills of Students through Differentiated Science Inquiry Integrated with Mind Map. Journal of Turkish Science Education (TUSED), 14(4): 71-91.

Zubaidah, S., Mahanal, S \& Yuliati, L. (2013). Ragam Model Pembelajaran IPA Sekolah Dasar [Various Science Learning Models of Elementary Schools]. Teacher Quality Improvement Program (TEQIP). Malang: State University of Malang. 